UDC 352.07:339.138

DOI: https://doi.org/10.32782/2224-6282/162-2

Rosokhata Anna
PhD,
Sumy State University
ORCID: https://orcid.org/0000-0001-6944-1515
Letunovska Nataliia
PhD,
Sumy State University
ORCID: https://orcid.org/0000-0001-8207-9178

Jasnikowski Adam

Postgraduate student,

Sumy State University;

Director, Fundacja EUROWEEK, Poland

Moiseienko Daria

Bachelor student,

Sumy State University

Росохата А.С., Летуновська Н.В., Ясніковскі А.М., Моісеснко Д.В. Сумський державний університет

\title{
MARKETING SERVICES MIX FOR HEALTHY TERRITORIES: EUROPE - UKRAINE FEATURES
}

The peculiarity of healthy territories is that this concept is complex and multifaceted. It includes implementing a healthy economy in some territory and security of public health in a particular territory. Therefore, from the standpoint of the territories' marketing as a component of the country's economy, it should be considered comprehensively. Usually, it is customary to use the $4 P$ complex for territory marketing, but when we research a healthy territory, this concept is continually changing over time and shaping its image. In this case, for the implementation of healthy territories marketing and its image, it is advisable to use additional elements of the marketing mix, which can describe the processes and the human factor and the conditions of the territory marketing.

Keywords: healthy territories, marketing services mix, territory image, territories marketing, marketing of healthy territories.

JEL classification: F20, L14, M31, O52

\section{КОМПЛЕКС МАРКЕТИНГУ ПОСЛУГ ДЛЯ ЗДОРОВИХ ТЕРИТОРІЙ: ОСОБЛИВОСТІ ЄВРОПИ ТА УКРАЇНИ}

Особливістю здорової території є те, що ие поняття є комплексним і різностороннім. Воно включає в себе як реалізацію здорової економіки на конкретній територій, так $і$ безпеку про здоров'я громадянина певної території. Стаття присвячена всебічному дослідженню такої категорії як «здорова територія» в умовах формування здорової економіки. Під поняттям здорової економіки розуміється максимально ефективне та оптимальне використання наявних ресурсів із балансуванням очікуваних вигод для всіх учасників економічних процесів на певній території. Реалізація цьього підходу можлива з урахуванням та дотриманням иілей сталого розвитку в цілому та реалізацією потенціалу кожної окремої особистості щодо участі у процесах, щьо формують ії оточення та сфери життєдіяльності, сприяють розвиткугромад на регіональному рівні та в рамках окремих територій. Для вирішення цього завдання використовуються інструменти комплексу маркетингу, щз спрямовані на вирімення завдань з просування та формування іміджу здорових територій та здорових економік. 3 позииії маркетингу території як складової економіки країни ї̈ необхідно розглядати комплексно. Зазвичай, прийнято використовувати до маркетингу територї̈ комплекс 4Р, але якщо говорити про здорову територію, то ие поняття в більшій мірі є процесом, який постійно видозмінюється в часі та формує імідж. Саме тому у даному випадку для здійснення маркетингу здорових територій та його іміджу доиільно використовувати додаткові елементи комплексу маркетингу, які можуть описати процеси та людський фактор, а також умови, у яких реалізується маркетинг території. Так, у статті відображено розподіл територіального маркетингу на дві основні складові - маркетинг територій і маркетинг на території. 3 огляду на це, проаналізовані складові класичного 4 Р маркетингового міксу з їхньою деталізачією щодо фактичної реалізаџї̈ у системі маркетингу здорових територій. Стаття представляе пропозицію щуодо долучення до класичних 4 Р елементів маркетингового комплексу три додаткових, які використовуються в маркетингу послуг. У подальшому пропонується їхня адаптація за змістом та наповненням до вирішення завдань маркетингу здорових територій. Крім того, у статті проаналізовані та наводяться приклади застосування розширених елементів комплексу маркетингу послуг у маркетингу окремих європейських територій (країн, міст), де зазначаються особливості маркетингового просування та позиціонування. I як результат, дослідження зводиться до аналізу обраної території в Украӥні (Сумський регіон). Для формування маркетингового міксу иієї території проведено SWOT-аналіз та запропоновано кроки щзодо ефективного позииіонування Сумського регіону на світовій арені як здорової території з позиції комплексу маркетингу послуг.

Ключові слова: здорові території, комплекс маркетингових послуг, імідж території, маркетинг територій, 
маркетинг здорових територій, позичіонування здорового регіону.

Problem statement. Nowadays, there are many actual questions for ineffective works of territorial communities' management on healthy territories' marketing services. The number of countries that respect the development of their territory and territorial marketing is highly significant. There is a question about the economic development of each country and each territory separately.

Given the precarious economic situation in Europe and Ukraine that started in 2020, one can see reducing the investment component and volatile state aid for some territory. It should understand that development of resource territories' potential will increase the competitiveness of marketing services among other more balanced territories.

The territory image has an influential character on the economic situation and the economy as a whole. The territory image and reputation are perhaps the essential factors in promoting marketing services in all countries.

Analysis of recent research and publications. Such scientists as G. Ashworth [1, 2], F. Kotler [16], V. Vakulenko [29], I. Drobiazko [8], P. Pankrukhin [21], D.V Vizgalov [32], T. Zhabinska [31], M. Oklander [32] etc. performed the research of marketing services tools. They showed considerable interest and made a significant contribution to the development of local marketing. Dinnie Keith [6; 7], Yu. Shatava, M. Karpishchenko [35] analyzed different categories in territories marketing. The researchers' main goal was to promote the image and reputation of the territory to give an opportunity for potential users of the territory to fully realize and analyze their distinctive features of advantage to distinguish their territory from others. Note that the concept of "marketing territories" scientists understand both the marketing of the region and the city's marketing in general.

The article aims to study and analyze the elements of the marketing complex for a healthy economy and relevant tools for its implementation.

Tasks of the article:

- to substantiate the approach to the formation of the territorial marketing complex;

- to explore marketing tools for healthy areas;

- to determine the features of the marketing of healthy areas of Europe;

- to analyze the peculiarities of the application of elements of the marketing complex in Ukraine on the Sumy region's example.

Presenting the main material. There are a few types of territorial marketing. Some people believe that marketing of territories is used only at the level of the country and region, reflecting and taking into account the specifics of a particular region, such as V. Vakulenko [29], I. Drobiazko [8], C. Yeremeev [10], F. Kotler [17]. Others believe that marketing of the territory (of each city together) carries out the implementation of improving the image and reputation and self-awareness. Applying the so-called set of marketing tools, namely advertising and public relations (N. Ilchenko [12;13], V. Shchelkunov, V. Gramotnev, V. Matveev [25].

In our opinion, the marketing of territories is two completely independent interpretations of words. The term "marketing" means a holistic system of selling goods or services from producer to potential consumer, which includes market and competitor analysis, packaging development and design, consumer and sales incentive system, and advertising.

At the present stage of domestic and foreign scientific thought development, the "region" concept has become widespread. Despite this, there is no single point of view on this concept's essence, which is due to the possibility of ambiguous interpretation of this category. According to $\mathrm{V}$. Symonenko, the economic territory is a region that stands out for its economic and geographical location, natural, labor resources, specialization, economic structure, the integrity of environmental, demographic, and other issues, its role in the international division of labor.

Therefore, territorial marketing is a specialized marketing used by certain territories in their interests to change their opinion and impressions. The purpose of territorial marketing is to create, maintain, or change the opinions, intentions, and behavior of parties interested in improving and enhancing the territory.

Marketing of healthy areas involves the implementation of marketing activities for the effectiveness of a healthy economy. A healthy economy in a particular area involves:

- effective use of economic, scientific, labor potential for dynamic production of goods and services in healthy areas;

- creating equal conditions for balanced socioeconomic development of the regions;

- ensuring compliance with state social guarantees for every citizen, regardless of his place of residence.

The main task of marketing areas is to find resources in the directive of competing regions and find ways to separate and position their region to differ from all other identified target groups. Healthy marketing areas' task is to select and implement marketing activities that will promote the permission to take an exact and leading position in conditions of increased inter-territorial competition.

Healthy marketing goals:

- maintaining the competitiveness of enterprises located in the region;

- the attraction of new potential clients (enterprises) to the region;

- increasing the visibility of the territory outside the country.

Territory marketing is explicitly targeted at the territory and is implemented both inside and outside it. On-site marketing concerns a specific product or organization operating in the territory. Both marketing environments are components of territorial marketing (Figure 1).

The appearance of the city, buildings, jobs, housing, and various services as elements of urban goods, complementing residents' skills and abilities, their traditions and culture, together create the image of the city and its idea. The marketing of territories is often considered from the standpoint of marketing tools and are called "marketing mix 4P" (Table 1).

A marketing strategy can strengthen the company's position in the market and significantly increase its economic efficiency. Many people traditionally associate marketing with sales. However, its potential is much more comprehensive.

Once again, we have the opportunity to see this by applying multifaceted methods and principles in territorial marketing.

Marketing tools that make it possible to promote territorial marketing: 


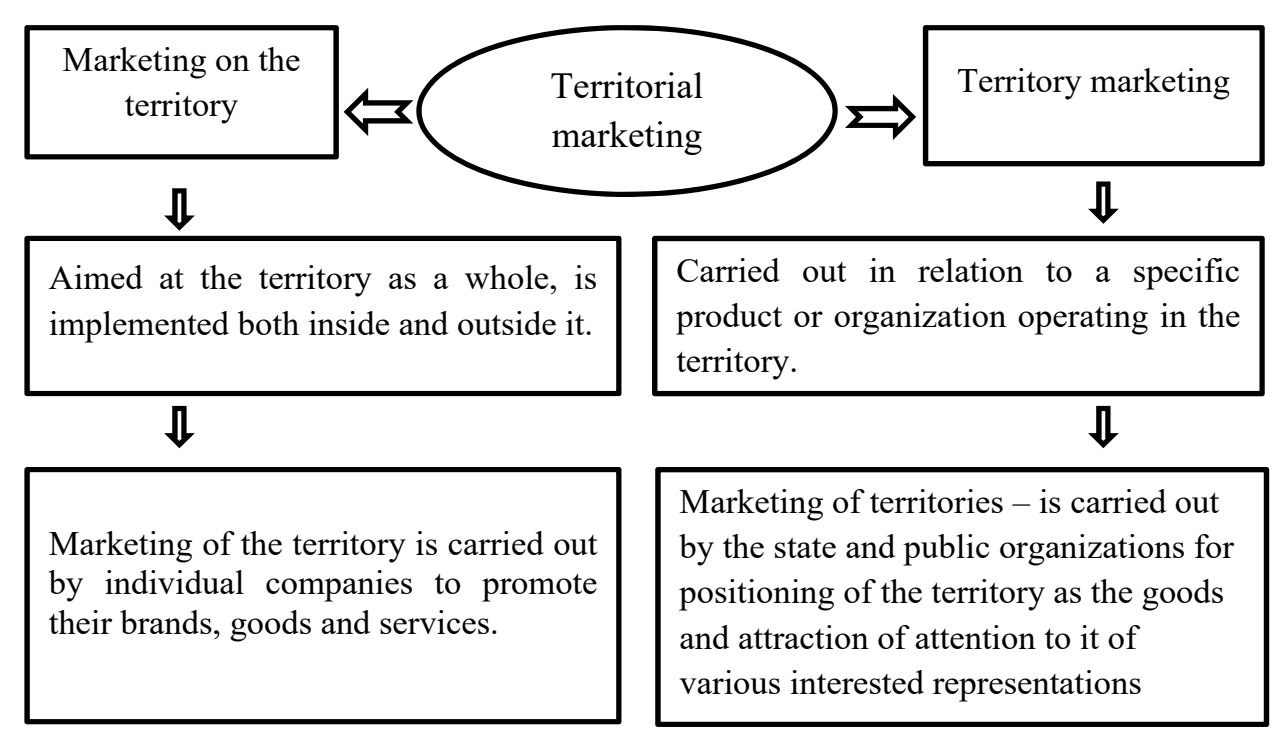

Figure 1. Territorial marketing and territorial marketing as part of territorial marketing

Components of the marketing complex 4P for marketing territory

Table 1

\begin{tabular}{|c|c|c|c|}
\hline \multicolumn{4}{|c|}{ "4P" in the marketing of territories } \\
\hline Product & Price & Place & Promotion \\
\hline $\begin{array}{l}\text { The product in territorial } \\
\text { marketing is the territory. } \\
\text { For the territory to } \\
\text { develop effectively, it is } \\
\text { first necessary to conduct } \\
\text { a detailed description, } \\
\text { analysis, and assessment } \\
\text { of the territory's } \\
\text { competitiveness. The } \\
\text { advantages for the territory } \\
\text { are location (geographical } \\
\text { location), raw material } \\
\text { resources, quality of life, } \\
\text { infrastructure, level of } \\
\text { business development of } \\
\text { the small, medium, large } \\
\text { enterprises, access to } \\
\text { capital, etc. }\end{array}$ & $\begin{array}{l}\text { The concept of the price } \\
\text { will mean the action that } \\
\text { the entrepreneur expects } \\
\text { after the effective } \\
\text { promotion of the object. } \\
\text { How satisfied he will } \\
\text { be with the expected } \\
\text { result. That is the costs } \\
\text { of the inhabitants of } \\
\text { the territory. The price } \\
\text { factor includes many } \\
\text { components: the cost } \\
\text { of utilities, local taxes, } \\
\text { the cost of overcoming } \\
\text { administrative barriers, } \\
\text { sponsorship, charity, and } \\
\text { so on. }\end{array}$ & $\begin{array}{l}\text { These are actions that are related to } \\
\text { the product and its sale to the final } \\
\text { consumer. It is difficult to characterize } \\
\text { this component because the place } \\
\text { of sale of goods or services almost } \\
\text { always remains the same. Therefore, } \\
\text { there are almost no intermediaries. } \\
\text { This element of the territorial } \\
\text { marketing complex consists of } \\
\text { establishing business relations with } \\
\text { other territories, organizing various } \\
\text { fairs and exhibitions, concluding } \\
\text { contractual relations with potential } \\
\text { clients (for example, people who want } \\
\text { to move to the city). Guidelines for } \\
\text { the localization of territorial marketing } \\
\text { can be the placement of raw materials, } \\
\text { transport accessibility, personnel, and } \\
\text { consumers' flow. }\end{array}$ & $\begin{array}{l}\text { Marketing communication allows } \\
\text { local governments to establish } \\
\text { close ties with the local community. } \\
\text { To form the city and the region's } \\
\text { appearance, to characterize the } \\
\text { socio-economic profile, to identify } \\
\text { the advantages and disadvantages } \\
\text { of marketing areas, to learn } \\
\text { the wishes of people, to form } \\
\text { strategic and tactical decisions } \\
\text { on modernization. It is possible } \\
\text { to promote territorial marketing } \\
\text { in a general way or specifically } \\
\text { targeted. The general dissemination } \\
\text { of information aims at acquainting } \\
\text { all recipients with it properly. The } \\
\text { action aims at the emergence of } \\
\text { new investors and sponsors. }\end{array}$ \\
\hline
\end{tabular}

- advertising;

- PR (public relations);

- propaganda;

- personal contacts (personal sale);

- sales promotion;

- branding;

- direct marketing;

- sponsorship.

First of all, one must determine where advertising and distribution, and communication channels will be directed. After that, we develop media, form volumes of information, display modes, track its impact, and adjust.

Targeted promotion is more focused and active in its purpose. Actions aim at exit and interaction with already familiar investors, correctly selected target audience, is used the Internet e-mail.

The subjects can be local governments (deputies), various representations of territories, and specially informed people looking for potential investors and contacts with them (from the beginning to project financing). Usually, the budget for this promotion is quite useful. The better the goals and objectives are set, the more efficient and effective the program will be.

M. Oklander and D. Vizgalov [34] propose a slightly different concept of "4P" of territorial marketing (city). It is almost indistinguishable from the classic marketing complex but is partially modified.

It includes:

- structural policy;

- fiscal policy (adjustment of prices, taxes, tariffs, provision of tax credits, credit guarantees, etc.);

- policy to improve the formation of channels of physical distribution of economic entities (establishment and conclusion of contractual relations with other territories, organization of fairs and exhibitions);

- the policy of effective promotion of territorial 
marketing (conducting campaigns to improve, adjust, and maintain a positive image of the territory).

In the theory of marketing of the region and the city, sometimes the classical concept of the complex "4P" is supplemented by additional elements and becomes a marketing complex "7P".

A. Shromnik [26] proposed a new approach to marketing activities at the region and the city as a whole. "Marketing mix" acquires significant value in the field of services used in territorial marketing. Local governments' activities are closely linked to the promotion of services to internal and external customers and go beyond the impossible. Therefore, marketing relevance is gaining momentum and goes beyond the classical concept.

In the theory of marketing, M. Florek [11] proposed to supplement the complex "4P" with two additional elements (staff, people). In turn $[12 ; 25]$, the scientists suggest to allocate the following components:

- staff;

- physical records;

- process.

These concepts are ideal for marketing areas, as the vast majority of local governments focus on providing all types of services. Each region and city forms its complex from 4P marketing areas to 7P, for successful use. This is determined by the harmonious combination of its tools and coordination with the territory's strategic goals. Elements of 7P are already used in the marketing of some European countries (Table 2), and this, in combination with other tools, helps them come to a healthy economy.

Factors determining the need for active implementation of territorial marketing in the tools of regional policy:

- the need to find a niche for this area among the influential areas of the world. For example, the brand capital of Paris is a tourist attraction, Germany is a car power, London is a financial center, Singapore is the best airport in the world, Bangalore (India) is a software city;

- increasing responsibility for own marketing. Small towns are forced to look for strategies that would distinguish them in the market from all competitors;

- technological and communication revolution. It was believed that only such cities as London or Frankfurt could lead to financial and information services. However, now, these services are also provided in Prague, Dublin, or Krakow.

Having studied European countries' experience in the development of marketing of healthy areas, we have the opportunity to focus on specific areas of Ukraine. Yes, Ukraine is a reasonably large country to a greater extent compared to other European countries studied. It is advisable to consider a separate region, namely - Sumy region, as a territory for which it is urgent to carry out marketing activities to restore a healthy economy. Note

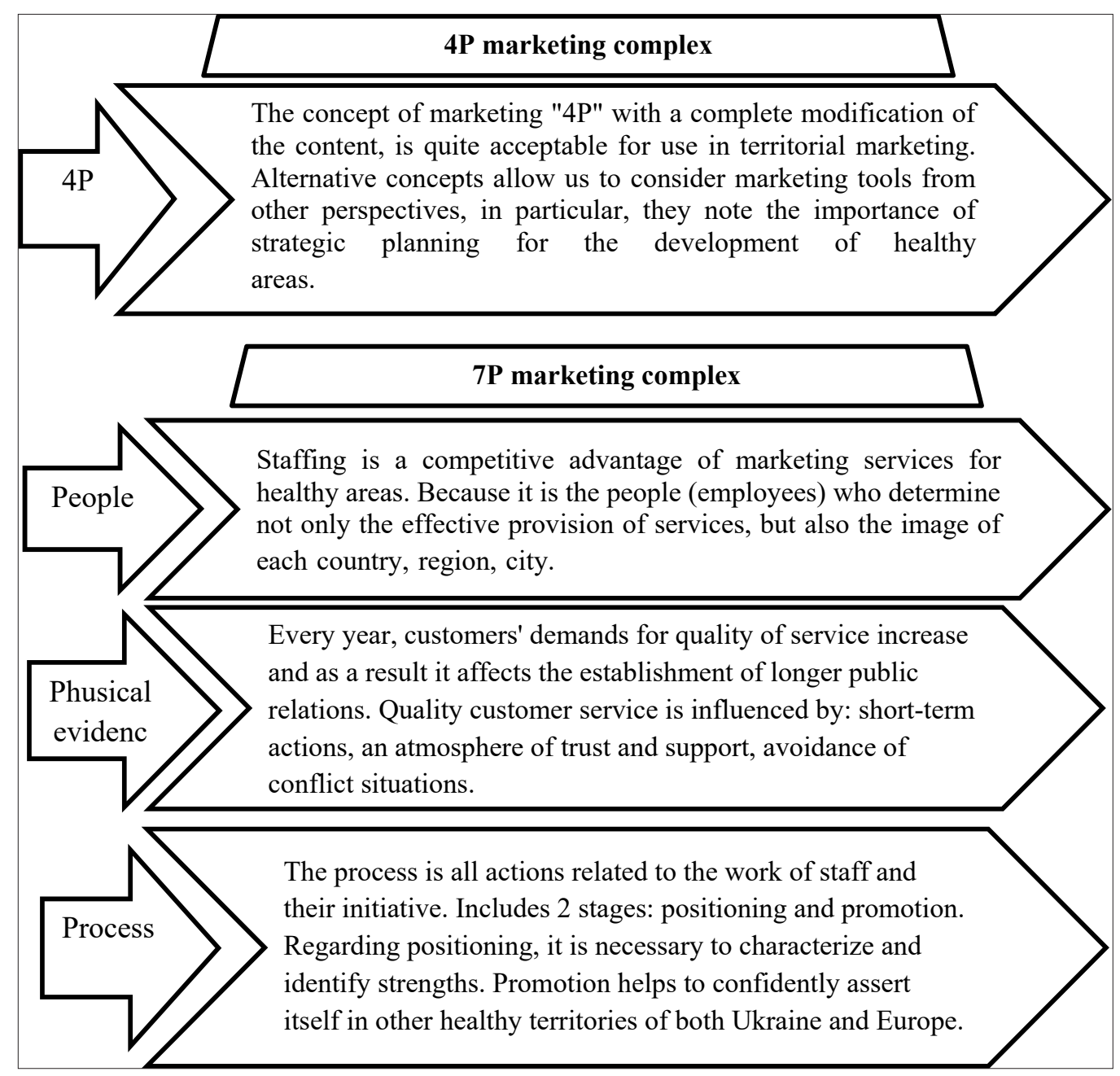

Figure 2. Expansion of the 4P marketing mix to 7P and detailing 
Table 2

Analysis of some European countries orientation to the territories marketing using 7P elements

\begin{tabular}{|c|c|c|c|}
\hline \multirow{2}{*}{\begin{tabular}{|c|} 
The country of Europe \\
and its territories \\
marketing orientation \\
(the element of the \\
marketing mix 7P) \\
\end{tabular}} & \multicolumn{3}{|c|}{ Added elements of the 7P marketing complex for the territories of European countries } \\
\hline & People & Physical evidence & Process \\
\hline $\begin{array}{l}\text { Sweden. } \\
\text { It uses an approach to } \\
\text { the development of the } \\
\text { marketing component } \\
\text { "people" (staff and the } \\
\text { public) }\end{array}$ & $\begin{array}{l}\text { They support the } \\
\text { territory population's } \\
\text { motivation to form a } \\
\text { positive attitude towards } \\
\text { guests, their involvement } \\
\text { in the territory or city. }\end{array}$ & $\begin{array}{l}\text { Sweden guarantees a tolerant, politically } \\
\text { correct attitude to everyone, regardless } \\
\text { of their views, values, and way of life, at } \\
\text { the level of residents' everyday behavior, } \\
\text { actions of the police and migration service, } \\
\text { the entire administration, and other } \\
\text { influential groups. }\end{array}$ & $\begin{array}{l}\text { In Sweden, the marketing } \\
\text { strategy of people (the population } \\
\text { and staff) is the most advanced, } \\
\text { as the Sweden positioning is } \\
\text { based on the formation and } \\
\text { maintenance of motivation into } \\
\text { the territory }\end{array}$ \\
\hline $\begin{array}{l}\text { Denmark. } \\
\text { It aims to provide } \\
\text { support for marketing } \\
\text { activities in the region } \\
\text { from within. }\end{array}$ & $\begin{array}{l}\text { The main task is, on } \\
\text { the one hand, in the } \\
\text { formation of local } \\
\text { patriotism. On the } \\
\text { other - in the formation } \\
\text { and maintenance of } \\
\text { friendly motivation } \\
\text { within the region for } \\
\text { non-regional residents } \\
\text { and structures, their } \\
\text { attractiveness to the } \\
\text { region. }\end{array}$ & $\begin{array}{l}\text { In Denmark, a system of visual } \\
\text { identification has been developed, part } \\
\text { of the famous multi-colored ovals with } \\
\text { the inscription "Open". This idea means } \\
\text { openness to tourists, new residents, and } \\
\text { technology. It also means a willingness to } \\
\text { tolerate, neutrally or positively perceive } \\
\text { the possibility of a number of unusual } \\
\text { ways of life of other people or peoples, } \\
\text { their values and culture. }\end{array}$ & $\begin{array}{l}\text { Denmark uses a self-developed } \\
\text { urban marketing program based } \\
\text { on the values of openness, } \\
\text { innovation, tolerance, creativity } \\
\text { to the people of the country. It is } \\
\text { also open to tourists, modern and } \\
\text { creative people and investments. }\end{array}$ \\
\hline $\begin{array}{l}\text { Helsinki. } \\
\text { In media, the city is } \\
\text { presented as a cultural } \\
\text { center life, scientific } \\
\text { and innovative, sports, } \\
\text { dance, and street art. }\end{array}$ & $\begin{array}{l}\text { Helsinki has numerous } \\
\text { successful, world- } \\
\text { renowned design } \\
\text { bureaus and schools. } \\
\text { Especially strong } \\
\text { Finnish furniture and } \\
\text { hi-tech designers. }\end{array}$ & $\begin{array}{l}\text { The system of traditional Scandinavian } \\
\text { "green" values has become key on the } \\
\text { Helsinki platform of the city marketing } \\
\text { brand. In this case, the branding strategy } \\
\text { (environmental ideas) has become a } \\
\text { fundamental tool in urban policy. A } \\
\text { decision was made to reduce air pollution } \\
\text { from the parking lot, financed from the city } \\
\text { budget, by purchasing electric cars, cars } \\
\text { with hybrid and diesel engines. Traffic has } \\
\text { been optimized using state-of-the-art traffic } \\
\text { control systems. In several "bottlenecks," } \\
\text { the shortest exits on high-speed ring roads } \\
\text { were broken, as a result of which drivers } \\
\text { travel a shorter distance, use less fuel and } \\
\text { do not pollute the environment. }\end{array}$ & $\begin{array}{l}\text { The main tasks that the state of } \\
\text { Helsinki set itself were: } \\
\text { - ensuring attractiveness in } \\
\text { three directions: as a place of } \\
\text { residence, as a place of rest and } \\
\text { as a place of business; } \\
\text { - focus on the interests of } \\
\text { citizens and investors as the } \\
\text { main prerequisite for regional } \\
\text { marketing. } \\
\text { Today, the strategy of marketing } \\
\text { attractiveness of the region } \\
\text { prevails. However, the Helsinki } \\
\text { region authorities are trying to } \\
\text { develop an integrated approach } \\
\text { to defining a marketing strategy, } \\
\text { partially implementing each of } \\
\text { the tasks. }\end{array}$ \\
\hline
\end{tabular}

that the current image of the city of Sumy is not bad enough compared to other cities in Ukraine.

For a detailed acquaintance with the city and the Sumy region's territory as a whole, a SWOT-analysis was conducted. SWOT-analysis, in this case, serves as an examination of the internal strengths (weaknesses) and weaknesses (weaknesses) of the region, opportunities (opportunities), and threats (threats) of the external environment.

For the region, it is characterized as follows:

- strengths - the advantages of the region (natural and acquired);

- weaknesses - shortcomings in the functioning of the region and its management;

- opportunities - factors and factors of the external environment, the use of which will allow the region to be better in the market and allow more successful development;

- threats - factors that can worsen the situation in the region.

After the SWOT-analysis, one identifies the strengths and opportunities of the external environment from the most promising to the least promising, and weaknesses and threats - from the most severe and significant. This is the beginning of laying the foundation for selecting the target audience and further forming the marketing strategy of services for the selected area - the city of Sumy.

According to the SWOT analysis of Sumy, the vital point is the environment, which, combined with the beauty of natural forms, essential prerequisites for most opportunities - positioning Sumy as a "comfortable city" and overall reproduction of a healthy economy. Sumy region. A vital point is the creative, exciting, and talented people who live in this area and the existing mentality of integrity, mutual support, and understanding.

The weak point is the lack of quality information policy to promote the city as a product, lack of support and timely operational assistance from the state, and the existing syndrome of "provincial city". In order to implement the strategy of the city of Sumy and the region of Sumy region as a healthy territory and its positioning in Ukraine and the world, it is advisable to focus primarily on management 
SWOT-analysis of Sumy region as an object of territorial marketing

Table 3

\begin{tabular}{|c|c|c|}
\hline \multicolumn{2}{|r|}{ Favorable factors } & \multirow{2}{*}{$\begin{array}{c}\text { Unfavorable factors } \\
\text { Weaknesses }\end{array}$} \\
\hline & Strengths & \\
\hline $\begin{array}{l}\text { Internal } \\
\text { factors }\end{array}$ & $\begin{array}{l}\text { 1. Good and clean ecology of the city. } \\
\text { 2. The average level of wages. } \\
\text { 3. Unsurpassed beauty of nature. } \\
\text { 4. Opportunity to obtain higher education in prestigious } \\
\text { universities. } \\
\text { 5. Respect for the guests of the city. } \\
\text { 6. Opportunities to open business. } \\
\text { 7. The presence of tourist attractions with related } \\
\text { infrastructure. } \\
\text { 8. Saturated cultural life. } \\
\text { 9. High activity of youth and public sector. }\end{array}$ & $\begin{array}{l}\text { 1. Lack of quality information policy to promote the city as } \\
\text { a product. } \\
\text { 2. Outflow of able-bodied population abroad. } \\
\text { 3. Low level of tourist attractiveness. } \\
\text { 4. High unemployment and at the same time labor shortage. } \\
\text { 5. There is a syndrome of "provincial city". } \\
\text { 6. A small number of architectural structures. }\end{array}$ \\
\hline & Opportunities & Threats \\
\hline $\begin{array}{l}\text { External } \\
\text { factors }\end{array}$ & $\begin{array}{l}\text { 1. Raising the rating among other cities. } \\
\text { 2. Opportunity to position Sumy as a "comfortable city". } \\
\text { 3. Positive changes in legislation. } \\
\text { 4. Obtaining cheap foreign loans. } \\
\text { 5. Obtaining external financial resources for the } \\
\text { implementation of European projects. }\end{array}$ & $\begin{array}{l}\text { 1. Strong competition with neighboring territories. } \\
\text { 2. Inflation. } \\
\text { 3. The threat of deteriorating the perception of the Sumy } \\
\text { region's brand as a separate territory. } \\
\text { 4. Instability of the political situation. } \\
\text { 5. Ecological pollution of the region. }\end{array}$ \\
\hline
\end{tabular}

efforts on specific components of the marketing services complex (7P).

The component "People" is singled out as one that is the most promising for the further development of marketing of the territory to stabilize a healthy economy. Figure 3 presents the main groups of the component "People" (People) marketing complex 7P for marketing in the Sumy region and Sumy.

One characterizes the Sumy region in terms of the marketing strategy of services provided to residents. If to ask Sumy residents do they like the city where they live, most would say: yes. Sumy region and the city itself is comfortable to live. Here are the main factors that influence this:

- convenient geographical location;

- exciting and rich historical and cultural heritage;

- city of information technologies;

- center of good education;

- provision of a wide range of medical services;

- variety of opportunities for leisure;

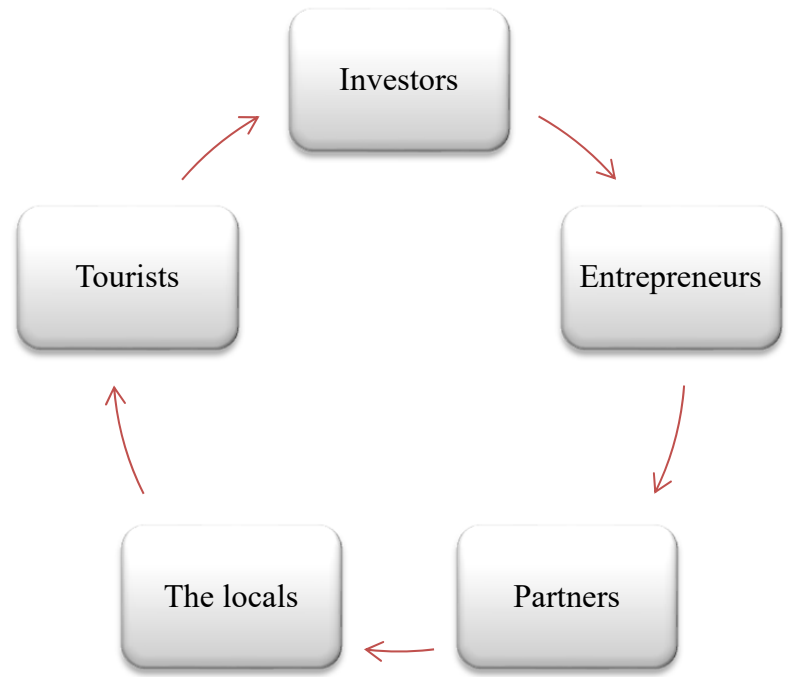

Figure 3. The main groups of the target audience in Sumy
- effective management;

- active public.

First of all, it is necessary to compare the functions of marketing management of the city clearly:

1. Development of a strategy for the development of the city of Sumy.

2. Monitoring and evaluating the effectiveness of the Sumy City Development Strategy.

3. Finding ways to carry out investment activities in the city of Sumy.

4. Attracting additional sources of funding for the implementation of the proposed projects.

5. Clear organization of work to create a marketing strategy.

6. Development and implementation of marketing activities for building the image of the city.

7. Creating conditions for tourism development in Sumy and the region. They are finding ways to expand the range of services in the hospitality industry, creating and improving the city's unique tourist offer.

Therefore, one of the prerequisites for the successful implementation of marketing strategy - is to convey information about it to as many residents of the community, stimulate their activity and involvement in the implementation process.

Conclusions. So, for each region and city in particular and each territory, it is possible to find remarkable differences between competitors. The use of marketing services tools is gaining importance in today's environment. This is evidenced by scientific publications, which are increasingly appearing in this field and practical developments.

Local governments have not had a systematic approach to good marketing activities yet. Therefore, we conclude that this issue will take time to resolve and different options for finding events. An insufficient number of economic marketing strategies developed in Ukraine leads to a low image of regions and cities. The use of territorial marketing concepts in the development of economic strategies will make it possible to attract investment to the region more successfully, increasing the attractiveness among foreign 
countries. In general, it will improve the territories' image and have a positive impact on their socio-economic situation.

\section{References:}

1. Ashworth G.J., Voogd H. (1990) Selling the city: marketing approaches in public sector urban planning. Belhaven, London. $178 \mathrm{p}$.

2. Ashworth G.J, Markowski T., Voogd H. (1990) Selling the City. Marketing Approaches in Public Sector UrbanPlanning. London: Belhaven Press.

3. Rosokhata A., Saher L., Stoyanets N., Butrym O. (2020) Impact Of Highly Qualified Personnels Migration On Economic And Innovative Development. 35th IBIMA Conference: 1-2 April 2020, Seville, Spain.

4. Bilan Y., Lyeonov S., Lyulyov O., Pimonenko T. (2019) Brand management and macroeconomic stability of the country. Polish Journal of Management Studies, no. 19, pp. 61-74.

5. Current issues of public administration: Coll. Science. works / editor. G.I. Mostovy, V.Ya. Ambrosov, O.Yu. Amosov and others. Kharkiv: RINADU «Master», 2011. No. 3 (18). 272 p.

6. Dinnie Keith (2011) City Branding: Theory and Cases. 1 edition. Palgrave Macmillan. 256 p.

7. Dinnie Keith (2007) Nation branding: Concepts, Issues, Practice. Taylor \& francis. 288 p.

8. Drobiazko I.M. (2007) Possibilities of using marketing technologies in the activities of local governments. State Construction: [electronic scientific professional publication of the Kharkiv Regional Institute of Public Administration of the National Academy of Public Administration under the President of Ukraine]. No. 1, part 2. Available at: http://www.nbuv.gov.ua.

9. Drobiazko I.M. (2008) Territorial marketing as a mechanism for improving the efficiency of local government. Theory and practice of public administration: collection. Science. pr. Kharkiv: HarRI NAPA Publishing House "Master". Issue. 2 (21), pp. 149-153.

10. Eremeev S.N. (2008) Formation and improvement of the image management mechanism of the region. Problems of theory and practice of economic systems management. Moscow: Yzd-vo RAHS.

11. Florek M. (2006) Podstawy marketingu terytorialnego. Poznań: Wydawnictwo Akademii Ekonomicznej w Poznaniu, 187 p.

12. Ilchenko N.V., Mazur R. (2010) The concept of participation and methods of involving the population in the development of the territorial community. State management: improvement and development, no. 7. Available at: http://www.dy.nayka.com.ua.

13. Ilchenko N.V. (2009) Community marketing - a means of economic development of the community / N.V Ilchenko, M.K Grigor. Proceedings of the X International Conference "Theory and Practice of Modern Economy". Cherkasy: ChTTU. Vol. 2, pp. 37-39.

14. Knyazeva I.V. (2007) Marketing of territories / I.V. Knyazeva, E.V. Shevtsova. Novosibirsk: SibAGS, 200 p.

15. Klody N.A. (2016) Economics feelings and experiences in tourism and management, teach, guide for Magistrate. Moscow.

16. Kotler F. (2015) How to conquer cities and countries. Moscow: Exmo.

17. Kotler P., Haider D.H., Rein I. (1993) Marketing Places: Attracting Investment, Industry, and Tourism to Cities, States, and Nations. The Free Press, New York. 400 p.

18. Keller K.L. (2007) Strategic brand management: building, measuring, and managing brand equity. Upper Saddle River. Prentice Hall, New Jersey. $692 \mathrm{p}$.

19. Moroz L.A (2002) Marketing: Textbook / L.A. Moroz, N.I. Chukhray; For order. L.A. Frost. - 2nd type. Lviv: National University "Lviv Polytechnic" (Information and Publishing Center "INTELLECT+" of the Institute of Postgraduate Education), "Intellect-West", $244 \mathrm{p}$.

20. Oleschuk M.G., Lyeonov S.V. (2014) Activities of credit unions: world experience and prospects of operation on the domestic market of credit services. Problems and prospects of development of the banking system of Ukraine: coll. Science. Works, UABS NBU, no. 39 , pp. $117-126$.

21. Pankrukhin A.P Marketing territories. with. 51.

22. Pankrukhin A.P Marketing territories. with. 23-27.

23. Pimonenko T. (2018). Ukrainian Perspectives for Developing Green Investment Market: EU Experience. Economics and Region, no. 4 (71), pp. 35-45.

24. Rahmanov F., Aliyeva R., Rosokhata A., Letunovska N. (2020) Tourism Management in Azerbaijan Under Sustainable Development: Impact of COVID-19. Marketing and Management of Innovations, no. 3, pp. 195-207. DOI: http://doi.org/10.21272/ mmi.2020.3-1.

25. Saher L.Yu., Syhyda L.O., Gryshova I. (2018) Current state and prospects for the development of innovative activity of industrial enterprises in Ukraine and the world. Innovative management: theoretical, methodical and applied grounds. 1st edition, Prague Institute for Qualification Enhancement: Prague, pp. 83-96.

26. Shchelkunov V., Bondarenko V., Karakay Y., Gramotnev V., Matveev V., Chekhomsky V., Romanovsk R. (2005) Marketing of regions: investment aspects. Kyiv: Naukova Dumka, 176 p.

27. Szromnik A. (1997) Marketing terytorialny - geneza, rynki docelowe i podmioty oddziaływania. Marketing terytorialny. Strategiczne wyzwania dla miast i regionów: pod red. T. Domaskiego. Łódź: Uniwersytet Łódzki, 216 p.

28. Szromnik A. (2011) Marketing terytorialny jako atrvbut rynkowej orientaeji miast i regionow // Grzegorczyk A., Kochaniec A. (eds.) Kreowanie wizerunku miast. Warszawa: Wyzsza SzkolaPromocji, pp. 18-41.

29. Ugryumova A.A. (2016) Regionalna ekonomika i upravlinnia / A.A. Ugryumova, E.V. Yerokhina, M.V. Savelieva. Moscow.

30. Vakulenko V. (2002) Urban marketing as a tool for strategic planning of economic development of the city. Management of the modern city, no. 4-6 (6). pp. 92-95.

31. Vasylieva T., Lyulyov O., Bilan Y., Streimikiene D. (2019) Sustainable economic development and greenhouse gas emissions: The dynamic impact of renewable energy consumption, GDP, and corruption. Energies, no. 12 (17). DOI: 10.3390/en12173289.

32. Vasilchenko G. (2010) Community passport as analytical information for managing the development of the territory. Economic analysis, vol. 6. pp. 392-395.

33. Vizgalov D.V. (2011) Branding of the city. Moscow: Foundation "Institute of City Economics".

34. Vizgalov D.B. Branding of the city, p. 14.

35. Vizgalov D., Mykhailo O. (2015) Let the city live / comp. M. Gubergritz, N. Zamyatina, M. Dedovsky. Moscow: ector.

36. Shatava Yu.L., Karpishchenko M.Yu. (2012) The mechanism of territorial branding development. Marketing and Management of Innovations, no. 4, pp. 324-329.

37. Tielietov O.S., Letunovska N.Ye. (2014) Organizational and economic mechanism of industrial enterprises social infrastructure management. Actual Problems in Economics, no. 160, pp. 329-337. 